\title{
Cytokine responses in primary chicken embryo intestinal cells infected with Campylobacter jejuni strains of human and chicken origin and the expression of bacterial virulence-associated genes Yi-Ping Li*1, Hanne Ingmer ${ }^{3}$, Mogens Madsen ${ }^{2}$ and Dang D Bang1
}

Address: ${ }^{1}$ Department of Poultry, Fish and Fur Animals, National Veterinary Institute (VET), Technical University of Denmark (DTU), Hangøvej 2, DK-8200 Aarhus N, Denmark, ${ }^{2}$ Dianova, Technical University of Denmark (DTU), Hangøvej 2, DK-8200 Aarhus N, Denmark and ${ }^{3}$ Department of Veterinary Pathobiology, Life Science Faculty, University of Copenhagen, Stigboejlen 4, DK-1870 Frederiksberg C, Denmark

Email: Yi-Ping Li* - yiping.li@hotmail.com; Hanne Ingmer - hi@life.ku.dk; Mogens Madsen - MOGMA@dianova.dk; Dang D Bang - ddb@vet.dtu.dk

* Corresponding author

Published: 27 June 2008

BMC Microbiology 2008, 8:107 doi:10.1186/147|-2180-8-107
Received: 26 October 2007

Accepted: 27 June 2008

This article is available from: http://www.biomedcentral.com/I47I-2/80/8//07

(c) 2008 Li et al; licensee BioMed Central Ltd.

This is an Open Access article distributed under the terms of the Creative Commons Attribution License (http://creativecommons.org/licenses/by/2.0), which permits unrestricted use, distribution, and reproduction in any medium, provided the original work is properly cited.

\begin{abstract}
Background: Campylobacter jejuni is a major cause of inflammatory diarrhoea in humans and is considered a commensal of the gastroenteric tract of the avian host. However, little is known about the interaction between $C$. jejuni and the avian host including the cytokine responses and the expression of the bacterial genes. We have investigated the invasiveness of primary chicken embryo intestinal cells (CEICs) by C. jejuni strains of human and chicken origins and the production of proinflammatory cytokines as well as the expression of the bacterial virulence-associated genes during co-cultivation.

Results: $C$. jejuni strains are capable of invading the CEICs and stimulate these cells in a proinflammatory manner and during this interaction the expression of the bacterial virulenceassociated genes ciaB, dnaj and racR is increased. Furthermore, incubation of bacteria with conditioned cell- and bacteria-free media from another co-cultivation experiment also increased the expression of the virulence-associated genes in the $C$. jejuni chicken isolate, indicating that the expression of bacterial genes is regulated by component(s) secreted upon co-cultivation of bacteria and CEICs.

Conclusion: We show that under in vitro culture condition $C$. jejuni strains of both human and chicken origins can invade avian host cells with a pro-inflammatory response and that the virulenceassociated genes of $C$. jejuni may play a role in this process.
\end{abstract}

\section{Background}

Campylobacter is a spiral Gram-negative, thermophilic, obligate microaerobic bacterial genus that is ubiquitous in temperate environments [1]. Campylobacter jejuni is recognized as the leading cause of bacterial food-borne and water-borne enteric diarrhea in humans. In the United States and Great Britain, more than $1 \%$ of the population is infected with C. jejuni each year [2,3], and the incidence of $C$. jejuni-induced disease may be even higher in developing countries, where infection often goes unreported. The clinical symptoms of Campylobacter infection include watery to bloody diarrhea, abdominal pain, fever, headache, nausea and vomiting in acute infection, even a severe inflammation of the intestinal mucosa with an 
influx of professional phagocytes [4]. Mostly the infection of Campylobacter is self-limiting, but some infections are associated with more serious medical sequels such as Reiter's syndrome (reactive arthritis), Miller-Fisher syndrome (MFS) and Guillain-Barré syndrome (GBS) [5]. The Campylobacter-associated illness has become an economic and health burden in the world $[3,6]$. Although knowledge about the organism and host responses to infection has been growing rapidly in the past decades, the pathogenesis of $C$. jejuni is not yet well understood.

C. jejuni colonizes the intestinal mucosa of warm-blooded hosts, including farm animals and humans. Among these hosts the favored environment appears to be the intestines of avians, including chickens, that provide optimal temperature conditions for growth, e.g. $42^{\circ} \mathrm{C}$. Unlike in the colonization of humans, $\mathrm{C}$. jejuni colonizes the intestinal tracts of most mammals and birds at a high level with little or no pathology [7]. The differences of pathology between human and chicken may relate partly to the host immune system. Cytokines are central to the development of effective immunity against microbial pathogens. Previous studies have shown that C. jejuni can invade human-derived epithelial cell cultures $[8,9]$ and induce the production of a number of cytokines and chemokines during the course of experimental infections [10-15], as well as in clinical Campylobacter infections [16]. In general, cytokine responses have mainly been monitored on human-derived cell lines with only a few studies performed on chicken cells $[15,17]$ and none involving C. jejuni isolates of chicken origin. Furthermore, experimental colonization experiments have shown that passage through the chicken gut enhances the colonization potential and virulence of C. jejuni [18], suggesting that it is important to use C. jejuni of chicken origin in order to more closely mimic the interactions taking place in the avian gut. Therefore, we used primary chicken embryo intestinal cells (CEICs) as a model to compare the cytokine responses of CEICs elicited by $C$. jejuni strains of human and chicken origin, as well as the concomitant expression of the virulence-associated genes of $C$. jejuni.

\section{Results \\ Intracellular bacterial counts}

With the aim of determining whether C. jejuni is able to invade primary chicken embryo intestinal cells (CEICs), intracellular bacterial counts were performed using the gentamicin protection method [8]. For this purpose two C. jejuni strains, a Danish chicken isolate SC11 and a clinical human isolate HM5040, were investigated. Prior to the infection experiment, the motility and morphology of both isolates was checked under light microscopy. The results of invasion are shown in Figure 1. The number of intracellular bacteria for both SC11 and HM5040 were gradually increased from 1 to $4 \mathrm{~h}$ p.i. and declined to a

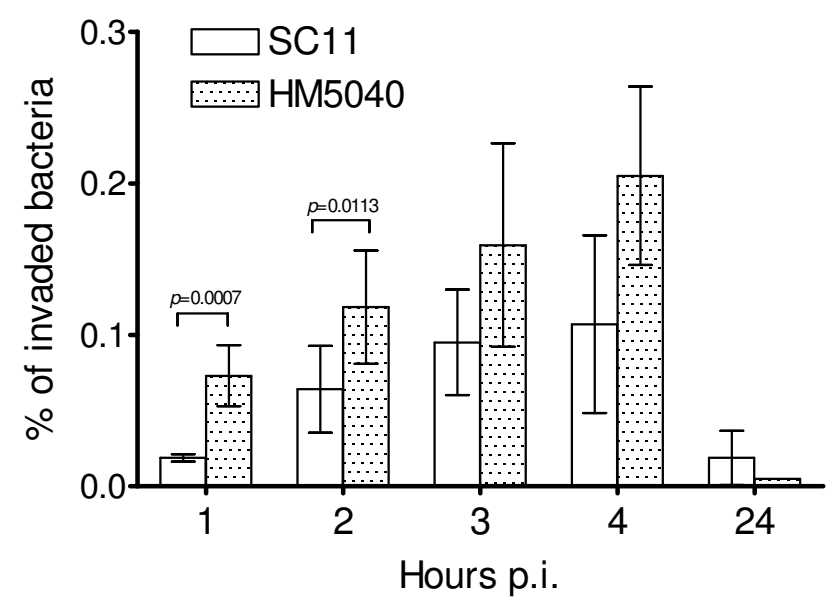

Figure I

Invasion of primary chicken embryo intestinal cells (CEICs) by C. jejuni. Cells grown at equivalent levels $(I .7 \times$ $10^{5}$ cells/well) were inoculated at an $\mathrm{MOI}$ of 100:I with either C. jejuni strain SCII (chicken isolate) or HM5040 (human isolate). The number of internalized bacteria was assessed by the gentamycin protection assay at I, 2, 3, 4 and $24 \mathrm{~h}$ post inoculation (p.i.). Data are representative of three independent experiments (average \pm SD).

lower level at $24 \mathrm{~h}$ p.i. The percentage of internalized SC11 overall was lower than that of HM5040 from 1 to 4 $\mathrm{h}$ p.i., with the exception of the $24 \mathrm{~h}$ p.i. where the number of internalized SC11 was higher than that of HM5040. A statistically significant difference between SC11 and HM5040 was observed only at 1 and $2 \mathrm{~h}$ p.i. ( $p$ $\leq 0.011)$.

\section{Production of cytokines by CEICs}

When human cells are in contact with $C$. jejuni a strong cytokine response is induced $[10,11,14]$. In order to determine if a similar response can be monitored with chicken embryo intestinal cells (CEICs), the levels of IL-1 $\beta$, IL-6, CXCLi1 (K60), CXCLi2 (CAF/IL-8) [19] and TGF- $\beta 4$ transcripts were measured in CEICs at 0, 1, 2, 3, 4 and $24 \mathrm{~h}$ p.i. with C. jejuni strains SC11 and HM5040. Mock-inoculated cells and those inoculated with LPS $(5 \mu \mathrm{g} / \mathrm{ml})$ were used as controls throughout. Figure 2 shows that both bacterial strains induced the production of IL-1 $\beta$, IL- 6 , CXCLi1 and CXCLi2, but not of TGF- $\beta 4$. The level of IL$1 \beta$, IL- 6 and CXCLi1 transcripts increased gradually from 1 to $4 \mathrm{~h}$ p.i. and declined slightly at $24 \mathrm{~h}$ p.i., whereas CXCLi2 transcript increased steadily throughout the observation period and reached a high level at $24 \mathrm{~h}$ p.i. Significant differences induced by SC11 and HM5040 were observed only at some particular time points: IL-1 $\beta$ at 24 h p.i. $(p=0.042)$, IL-6 at 4 p.i. $(p=0.012)$ and $24 \mathrm{~h}$ p.i. $(p=0.046)$ and CXCLi2 at 1 h p.i. $(p=0.025)$ and 24 

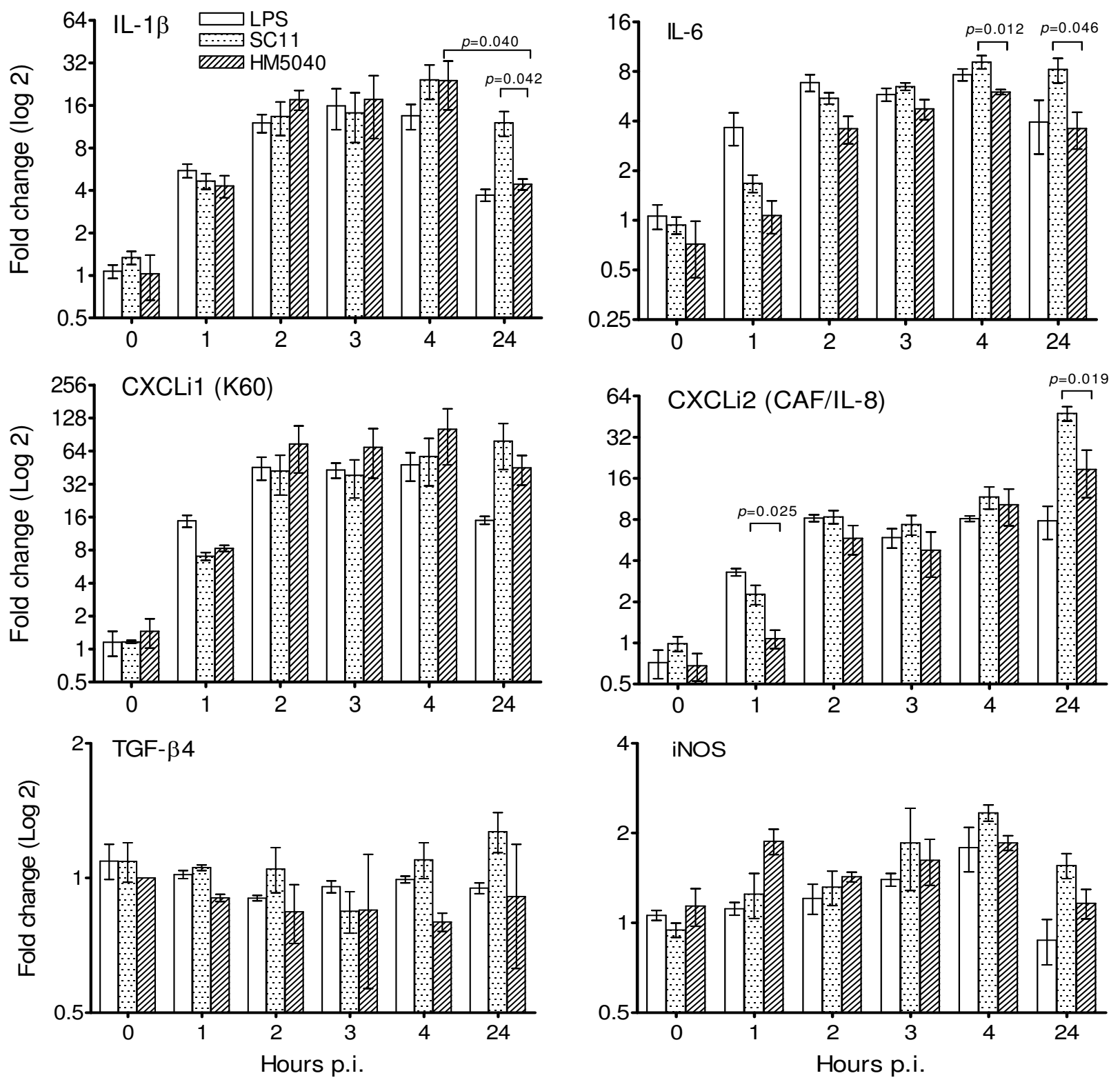

Figure 2

Quantification of cytokine and chemokine transcripts from primary chicken ebmryo intestinal cells (CEICs). CEICs were inoculated with C. jejuni strain SCII (chicken isolate) and HM5040 (human isolate) at a MOI of I00:I, RNA were isolated at various hours post inoculation (p.i.). LPS E. coli 055:B5 $(5 \mu \mathrm{g} / \mathrm{ml})$ and mock inoculation were used as controls. Data are representative of three independent experiments and present as relative to mock inoculations (average \pm SD) (see Methods for details).

h p.i. $(p=0.019)$ while IL-2 and IL-4 transcripts were undetectable. The transcript of IFN- $\gamma$ was detected only at some particular time points (data not shown).

\section{Induction of iNOS and production of NO by CEICs}

To study whether there are inflammatory responses in CEICs, the cellular iNOS transcripts and the presence of
NO product in the medium were measured. The level of iNOS transcripts was altered by both strains and increased gradually from 1 to $4 \mathrm{~h}$ p.i., followed by a decline at $24 \mathrm{~h}$ p.i (Figure 2). The production of NO from the inoculated CEICs was determined at 4 and $24 \mathrm{~h}$ p.i. using the Griess assay [20]. The results were presented as a net nitrite production over the background of the mock-inoculated 


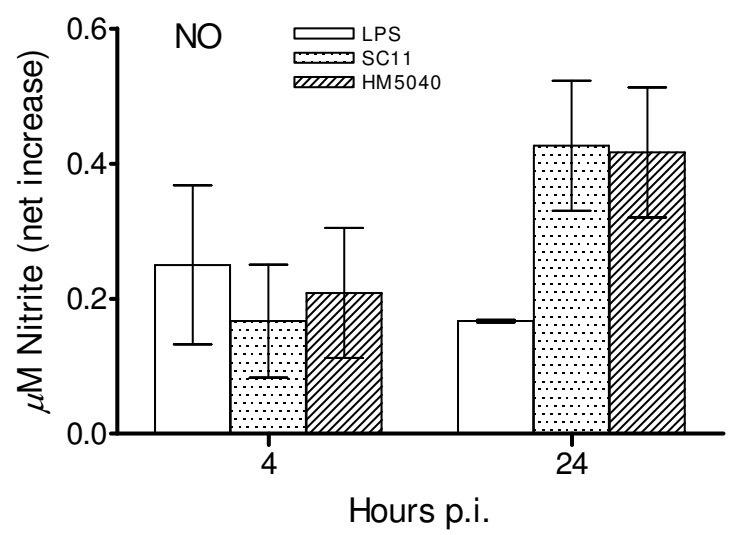

Figure 3

Production of nitric oxide (NO) by primary chicken embryo intestinal cells (CEICs). CEICs were inoculated with C. jejuni strain SCI I (chicken isolate) and HM5040 (human isolate) at an MOI of I00:I, and NO in supernatants were measured at 4 and 24 hours post inoculation (p.i.). LPS E. coli 055:B5 $(5 \mu \mathrm{g} / \mathrm{ml})$ and mock inoculation were used as controls. Data are representative of three independent experiments and are presented as net increases of $\mathrm{NO}$, from which the NO of the mock inoculations has been subtracted (average \pm SD).

CEICs (Figure 3). Nitric oxide was produced by inoculated CEICs, while as expected, the CEICs treated with LPS also showed NO induction.

\section{Expression of the virulence-associated genes of $\mathrm{C}$. jejuni}

To study whether the contact between C. jejuni and CEICs induce bacterial virulence-associated genes, the expression of bacterial virulence-associated genes ciaB, dnaJ and racR was quantitatively determined during co-cultivation with CEICs, relative to $16 \mathrm{~S}$ rRNA, and the fold change of the gene expression was determined relative to the mockincubated bacteria in the absence of CEICs. The results are shown in Figure 4. The transcription of the virulence-associcated genes was increased following co-cultivation with CEICs, and the amount of present in the invaded/adhered bacteria was generally higher than that present in the suspended bacteria, especially the transcripts of $d n a J$ and racR. ciaB transcription was increased at 1 and $2 \mathrm{~h}$ p.i. in SC11 and HM5040, respectively, and declined to a background level at $4 \mathrm{~h}$ p.i., followed by a slight increase at 24 $\mathrm{h}$ p.i. In the suspended bacteria, the expression of $c i a B$ was changed slightly, increased in SC11 and decreased in HM5040. A significant difference between SC11 and HM5040 was observed at 24 h p.i., where SC11 had a higher fold change than HM5040 had $(p=0.041)$. The transcripts of $d n a J$ and $r a c R$ in invaded/adhered bacteria were increased in both strains throughout the course of the experiment. A statistically significant difference was


\section{Figure 4}

Quantification of the expression of the virulenceassociated genes of $C$. jejuni. Primary chicken embryo intestinal cells (CEICs) were inoculated with $C$. jejuni chicken strain SCII and human strain HM5040 at a MOI of I00:I, total RNA was isolated, and the expression of ciaB, dnaj and racR of $C$. jejuni in internalized/adhered $(\mathrm{IA})$ and suspended (SU) bacteria were measured at various time points post inoculation (p.i.) (see Methods). Mock inoculation was used as control. Data are representative of those from three independent experiments relative to mock inoculations (average $\pm \mathrm{SD}$ ). 

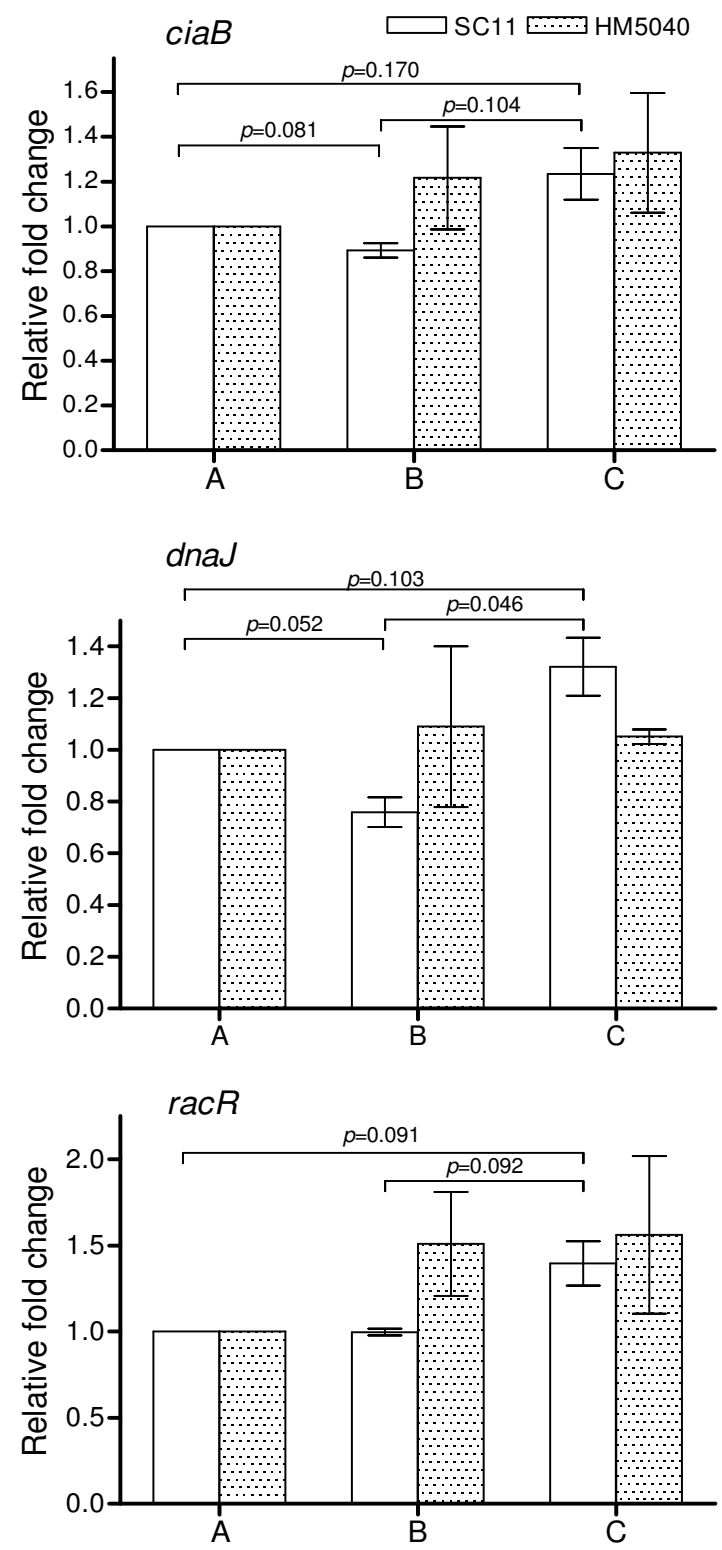

Figure 5

Quantification of the expression of virulence-associated genes of $C$. jejuni under different conditions. ciaB, dnaj and racR of $C$. jejuni strains SCII and HM5040 were measured in the bacteria incubated under different conditions, A) mock control, B) primary chicken embryo intestinal cells (CEICs) cultured medium, and C) bacteria- and cell-free supernatant from another co-cultivation experiment (see Methods). At $4 \mathrm{~h}$ post incubation (p.i.), total bacterial RNA was isolated, and the genes were quantitatively determined by real time quantitative PCR, relative to I6S rRNA. The level of the transcripts of mock control bacteria (A) was defined as I, to which the level of the genes in other bacteria ( $B$ and $C$ ) was relative. Data are representative of those from three independent experiments (average \pm SD). observed only for racR at 1 h p.i. $(p=0.020)$, the level of racR and dnaJ in SC11 was higher than that in HM5040 with the exception of $d n a J$ at $24 \mathrm{~h}$ p.i. In suspended bacteria, the expression of $d n a J$ and $\mathrm{racR}$ was altered slightly during the inoculation. The racR transcript in SC11 was significantly higher than in HM5040 at 24 h p.i. $(p=$ $0.029)$.

To examine whether the induction of the virulence-associated genes is contact dependent, the expression of the selected virulence-associated genes was also measured in the bacteria that had only been incubated with bacteriaand cell-free supernatant prepared from another co-cultivation experiments. The bacteria incubated with the medium from non-inoculated CEICs and mock-incubated bacteria were used as controls. The level of expression of the virulence-associated genes in mock-incubated bacteria was defined as 1 , to which the expression of the genes in the bacteria incubated with bacteria- and cell-free supernatant and cultured medium was calculated (Figure $5)$. After 4 hours of incubation, expression of the three virulence-associated genes $c i a B$, dnaJ and $r a c R$ of SC11 was increased slightly as compared to the mock-incubated bacteria and those bacteria incubated with the medium of non-inoculated CEICs $(p \leq 0.170)$. The medium of noninoculated CEICs decreased the expression of $c i a B$ and $d n a J$ in SC11 ( $p \leq 0.081)$, but did not alter the level of $r a c R$ transcripts. For HM5040, expression of the three genes showed a slight increase in both bacteria incubated with the medium of non-inoculated CEICs and bacteria- and cell-free supernatant $(p \leq 0.30)$.

\section{Discussion}

In this study, primary chicken embryo intestinal cells (CEICs) were used to study the commensal interaction between chicken intestinal cells and C. jejuni of human and chicken origin. The results clearly show that both $C$. jejuni strains of chicken (SC11) and clinical (HM5040) origin can invade CEICs to a level approximate to that seen with human-derived cell lines [21]. However, HM5040 demonstrated a higher percentage of internalized bacteria than SC11 at early stage after inoculation (1 and $2 \mathrm{~h}$ p.i., Figure 1). The internalized bacteria did not persist, and declined to a low level at $24 \mathrm{~h}$ p.i.. These results are consistent with previous studies, in which only a few viable bacteria remained intracellularly in human dendritic cells [22] and human peripheral monocytes/ macrophages [23] after a prolonged infection period (24 or $48 \mathrm{~h}$ ) with C. jejuni. In contrast, other studies have demonstrated that $C$. jejuni may survive intracellular for relatively long periods of time in both phagocytes and intestinal epithelial cells [24,25], and the phagocytosis may even promote the survival of C. jejuni [24], which has lead to its suggested classification as a facultative intracellular pathogen. The intracellular survival may enhance the 
ability of C. jejuni to evade the host immune system, possibly favoring its long-term persistent infections [26]. However, to survive, the intracellular bacteria also have to overcome certain challenges, such as hydrogen peroxide [26] and ferrous iron [27]. For C. jejuni and some other enteric pathogens, it is however still largely unclear as to which primary factor(s) determines intracellular bacterial survival.

We further studied the interaction of C. jejuni-avian host in the aspect of the cytokine responses to C. jejuni. The results showed that both $C$. jejuni strains investigated were capable of inducing the expression of the pro-inflammatory cytokines IL-1 $\beta$ and IL- 6 and the pro-inflammatory chemokines CXCLi1 and CXCLi2 in CEICs. Furthermore, we measured the production of iNOS and NO from CEICs. Inducible NOS was increased transcriptionally in CEICs at 4 h p.i. (Figure 2), and an increased NO level was also detected in the co-cultivated medium at 4 and $24 \mathrm{~h}$ p.i. (Figure 3). Inducible NOS, IL-1 $\beta$, IL-6, and CXCLi2 are major markers of inflammatory disease. Thus, it appears that C. jejuni can stimulate inflammatory responses in CEICs. Our results are consistent with previous reports using avian cells, in which Campylobacter induced proinflammatory cytokines and chemokines in avian primary chick kidney cells and the avian macrophage cell line HD11 [15], as well as in primary intestinal chick cells [17]. Interleukin-8 is a pro-inflammatory cytokine, a potent chemotactic factor for many immune effector cells, and a mediator of localized inflammatory responses [28]. Campylobacter strains have exhibited variability in the induction of CXCL8, and those strains with a high ability to invade intestinal epithelial cells frequently induce the high levels of CXCL8 [12]. Although HM5040 showed higher invasion efficiency than SC11 shortly after inoculation, we did not observe any convincing correlation linking the invasion efficiency to the induction of cytokines and chemokines. In addition, a previous study has demonstrated that the induction of CXCL8 from INT407 cells may be regulated by two independent mechanisms, one of which requires adherence and/or invasion and the other requires cytolethal distending toxin (CDT) [29]. The functional role of the avian CXCLi2 measured in this study awaits further investigations.

Potential virulence properties of Campylobacter include motility, chemotaxis, colonization ability, adhesion to intestinal cells, invasion and epithelial translocation, intracellular survival, and formation of toxins and a number of putative virulence genes have been reported among the Campylobacter isolates [30]. CiaB gene and racR gene are highly prevalent in Campylobacter isolates from various sources [31], and conserved across the species [32]. DnaJ is a functional homologue of the dnaJ gene from E. coli and plays a role in C. jejuni thermotolerance and colonization of chickens [33,34]. The RacR-RacS (reduced ability to colonize) system is a two-component regulatory system and is involved in the ability to colonize the chicken intestinal tract [35]. It is important to study how these genes react to the co-cultivation as they could provide more information about Campylobacter-host interaction and the pathogenesis of Campylobacter. We thus measured the expression of these virulence-associated genes at the transcriptional level. All the three virulence-associated genes were up-regulated in invaded/ adhered bacteria. The level of the expression in the suspended bacteria in contact with CEICs was generally lower than that in the internalized/adhered bacteria, which is likely a consequence of less direct contact than experienced by the internalized/adhered bacteria. Expression of $c i a B$ gene of the internalized/adhered bacteria was induced to a lower extent as compared to that of $d n a J$ and racR (Figure 4). Previously, in in vitro studies have shown that $c i a B$ is involved in the internalization of $C$. jejuni into host cells and required for the protein secretion process [36]. The up-regulation of the virulence-associated genes during the co-cultivation with and/or invasion into CEICs may suggest that these genes play a role in the invasion process of C. jejuni. Although few statistical differences were observed, SC11 showed in general a higher level of expression of these virulence-associated genes than observed in HM5040 except with a few differences (Figure 4). Shortly after inoculation ( 1 and $2 \mathrm{~h}$ p.i., Figure 1 ), the invasion efficiency of SC11 was significantly lower than that of HM5040. It is likely that the virulence-associated genes in SC11 are more inducible by co-cultivation with CEICs and this induction may decrease the invasion efficiency of SC11.

To study whether the induction of the virulence-associated genes is contact dependent, the bacteria were incubated with the bacteria- and cell-free supernatant from another co-cultivation experiments and with the medium of non-inoculated CEICs. The bacteria-and cell-free supernatant induced the expression of the genes tested to a greater extent in SC11 ( $p \leq 0.170)$ than in HM5040 ( $p \geq$ $0.30)$. The medium of non-inoculated CEICs suppressed the expression of the virulence-associated genes in chicken strain SC11, especially for genes ciaB and $d n a J$ ( $p$ $\leq 0.081$ ), while slightly increased in human strain HM5040 (Figure 5). Previous studies have showed that both host cell components and a cell-free serum-supplemented tissue culture medium can induce Cia proteins secretion, and the secretion of $C$. jejuni Cia proteins is contact dependent $[37,38]$. In our study, the results from SC11 may indicate that a physically contact of bacteria and CEICs is not necessary for the transcriptional up-regulation of the genes tested, since the induction of the genes occurred in those bacteria inoculated only with bacteria- and cell-free media prepared from an another co- 
cultivation experiments. These results may indicate that CEICs and/or bacteria secrete components into the environment after physical contact event(s). The secreted component(s) may subsequently initiate the expression of the virulence-associated genes in other bacterium that had never been physically contacted with either CEICs or invaded/adhered bacteria. Thus, the up-regulation of these virulence-associated genes may not be bacteria-cell contact dependent, but the secretion of the active component(s) is bacteria-cell contact dependent.

\section{Conclusion}

In summary, we have demonstrated that both $C$. jejuni strains of human and chicken origin can invade CEICs and stimulate CEICs to undergo an inflammatory response in a similar manner. The expression of virulenceassociated genes of $C$. jejuni is increased during the course of invasion, and may play a role in the invasion process.

\section{Methods \\ Bacteria}

Two C. jejuni strains SC11, a Danish chicken isolate, and HM5040, a human isolate, were used in this study. These two strains were the most common serotype (Penner serotype 2) and flaA type (flaA type 1) among isolates from broilers and human cases in Denmark [39]. Both strains were taken from $-80^{\circ} \mathrm{C}$ stock and streaked on modified CCDA (mCCDA) (blood-free agar base with cefoperazone [32 mg/liter] and amphotericin B [10 mg/liter]) (CM739 plus SR155; Oxoid, Basingstoke, UK) agar plates and incubated under microaerobic condition $(10 \%$ CO2, 2-4\% $\mathrm{H} 2$ and $86 \%-88 \% \mathrm{~N} 2$ ) at $42{ }^{\circ} \mathrm{C}$ for $48 \mathrm{~h}$. The bacteria were then sub-cultured on a new mCCDA plate for another $24 \mathrm{~h}$ prior to experimentation. The bacteria were harvested and well suspended in room temperature PBS $(10 \mathrm{mM})$ to an $\mathrm{OD}_{595}=1.0$ (approximately $10^{9}$ bacteria/ $\mathrm{ml}$ ). The bacteria were then diluted in pre-warmed Dulbecco's modified Eagle's growth medium (DMEM) (Invitrogen, UK) without antibiotics to the desired density for inoculation of cell cultures at a multiplicity of infection (MOI) of 100 bacteria per cell.

\section{Cell cultures}

Primary chicken embryo intestinal cells (CEICs) were prepared from 19-day-old specific pathogen free (SPF) chicken embryos (Lohmann Tierzucht GmbH, Cuxhaven, Germany). Briefly, SPF chicken embryos were dissected, and intestines were separated and cut into small pieces in PBS prior to being digested with $0.25 \%$ trypsin-EDTA (Invitrogen, UK) for 3 times, $5 \mathrm{~min}$ for each. The cells were then collected by centrifugation at $500 \times \mathrm{g}$ for $10 \mathrm{~min}$ at room temperature $\left(\sim 25^{\circ} \mathrm{C}\right)$. The cells were seeded in 12 -well plates at a density of $3.5 \times 10^{5}$ cells $/ \mathrm{ml}(1 \mathrm{ml}$ per well) in DMEM (Invitrogen) supplemented with $10 \%$ fetal bovine serum (FBS) (Invitrogen), 0.3\% (w/v) tryp- tose phosphate broth (containing $0.13 \%$ pancreatic digest of casein, $0.07 \%$ proteose peptone No. $3,0.02 \%$ dextrose, $0.05 \%$ sodium chloride, $0.026 \%$ disodium phosphate), and $0.02 \%$ penicillin and streptomycin each (Invitrogen). The cells were incubated in a humidified environment at $37^{\circ} \mathrm{C}$ with $5 \% \mathrm{CO} 2$ throughout the experiment. At $24 \mathrm{~h}$ the medium was replaced with fresh growth medium, the cells were incubated for anther $72 \mathrm{~h}$ prior to bacterial inoculation experiments. The cells were washed three times with pre-warmed PBS, freshly prepared $300 \mu \mathrm{l}$ of antibiotic-free medium containing the desired number of bacteria was added and co-cultivated with cells to various time points. All inoculations were carried out at a MOI of 100:1, unless stated otherwise. Controls consisted of mock infections using antibiotic-free medium alone or positive controls of lipopolysaccharide (LPS, $5 \mu \mathrm{g} / \mathrm{ml}$ ) (Sigma, Schnelldorf, Germany).

To prepare bacteria- and cell-free cultured medium, cells were inoculated with the desired number of bacteria for 4 $\mathrm{h}(\mathrm{MOI}=100)$, the medium was collected, the bacteria was removed by centrifugation three times at $10,000 \times \mathrm{g}$, $3 \mathrm{~min}$ for each, or filtration through a $0.22 \mu \mathrm{m}$ filter. Three hundred $\mu \mathrm{l}$ of this medium was added to freshly harvested bacteria of $\sim 1.7 \times 10^{7}$ and incubated for $4 \mathrm{~h}$. As controls, the bacteria incubated with fresh and CEICs-cultured medium were included in parallel. The incubated bacteria were collected by centrifugation and subject to bacterial total RNA isolation as described below.

\section{Intracellular bacterial counts}

The number of intracellular bacteria per eukaryotic cell culture was assessed by the gentamicin protection assay [8]. At 1, 2, 3, 4 and $24 \mathrm{~h}$ post inoculation (p.i.), the culture medium was removed, Hank's Buffered Salt Solution (HBSS, Invitrogen) containing gentamicin $(200 \mu \mathrm{g} / \mathrm{ml})$ was added, and incubated at $37^{\circ} \mathrm{C}, 5 \% \mathrm{CO} 2$ for $2 \mathrm{~h}$. The cells were then washed three times with pre-warmed PBS and lysed with $500 \mu \mathrm{l}$ of $0.2 \%$ (v/v) Triton X-100 at room temperature for $15 \mathrm{~min}$. The bacteria counts were numerated by plates counting and were present as a percentage of invaded bacteria to total inoculated bacteria.

\section{RNA extraction, reverse transcription, and PCR conditions} Total cellular and bacterial RNA was extracted using TRIZOL LS Reagent (Invitrogen) and re-purified using RNeasy Mini RNA isolation kit (Qiagen, Germany) according to the manufacturers's instructions. At $0,1,2,3,4$ and 24 h p.i., both the medium of the inoculation and the suspended bacteria were collected by centrifugation at $10,000 \times \mathrm{g}$ for $3 \mathrm{~min}$. The bacteria pellets and cells were lysed in $300 \mu$ l of TRIZOL LS reagent and proceed to RNA isolation. RNA was eluted into $50 \mu \mathrm{l}$ of RNase-free water and treated with $0.1 \mathrm{U} / \mathrm{ml}$ Dnase I Amplification Grade (Invitrogen) according to the manufacturer's protocol. 
The treated RNA was further tested for DNA contamination by PCR using the primer pairs of $\beta$-actin and $16 \mathrm{~S}$ rRNA (Table 1). DNA-free RNAs were transcribed to complementary DNA (cDNA) using the iScript ${ }^{\mathrm{TM}} \mathrm{cDNA}$ Synthesis Kit (Bio-Rad, USA) with pre-blended RNase inhibitor, oligo (dT) and random hexamer primers, according to the manufacturer's instructions. Quantitative real time PCR (qPCR) was performed in the Mx3005P thermocycler (Strategene, Denmark) using primers listed in Table 1. PCR mixtures $(25 \mu \mathrm{l})$ contained 0.625 units of Taq DNA Polymerase (Promega, Denmark), $5 \mathrm{mM}$ $\mathrm{MgCl} 2,200 \mu \mathrm{M}$ dNTPs, $400 \mathrm{nM}$ of each primer, $10 \mathrm{nM}$ fluorescein (Bio-Rad), $50000 \times$ diluted SYBR green (Invit- rogen), and $2 \mu$ l of diluted cDNA. The thermal cycling conditions included an initial heat-denaturing step at $94^{\circ} \mathrm{C}$ for $3 \mathrm{~min} ; 45$ cycles of $94^{\circ} \mathrm{C}$ for $15 \mathrm{~s}$, optimal annealing temperature for appropriate primer pair (Table 1) for $20 \mathrm{~s}$ and $72{ }^{\circ} \mathrm{C}$ for $20 \mathrm{~s}$; followed by an elongation step at $72^{\circ} \mathrm{C}$ for $3 \mathrm{~min}$. A single fluorescence measurement was taken after each thermo cycle. The specificity of amplifications was checked by melting curve analyses and $2 \%$ agarose gel. All primers gave specific melting curves and electrophoresis bands as expected (data not shown). The efficiency of the amplification for each primer pair was assessed by a slope of the equation of a standard curve generated from the serial dilutions of the pooled samples.

Table I: Genes and primers used in this study.

\begin{tabular}{|c|c|c|c|c|c|c|}
\hline Genes (Species) & $\begin{array}{l}\text { Primer sequences } \\
\left(5^{\prime}-3^{\prime}\right)\end{array}$ & $\begin{array}{c}\text { Annealing } \\
\text { temperatures }\left({ }^{\circ} \mathrm{C}\right)\end{array}$ & Amplicons (bp) & Standard curves & $\begin{array}{l}\text { Correlation } \\
\text { coefficient }\left(r^{2}\right)\end{array}$ & GenBank access no. \\
\hline $\begin{array}{l}\beta \text {-actin (Gallus } \\
\text { gallus/chicken) }\end{array}$ & $\begin{array}{l}\text { GAGAAATTGTGC } \\
\text { GTGACATCA } \\
\text { CCTGAACCTCTC } \\
\text { ATTGCCA }\end{array}$ & 63 & 152 & $y=-3.312 x+19.3$ & 0.997 & L08I65 \\
\hline $\begin{array}{l}\text { IL-I } \beta \text { (Gallus gallus/ } \\
\text { chicken) }\end{array}$ & $\begin{array}{c}\text { CTGGGCATCAA } \\
\text { GGGCTACA } \\
\text { GGCTGTCCAGG } \\
\text { CGGTAGA }\end{array}$ & 62 & 142 & $y=-3.359 x+25.3$ & 0.990 & AJ245728 \\
\hline $\begin{array}{l}\text { IL-6 (Gallus gallus/ } \\
\text { chicken) }\end{array}$ & $\begin{array}{c}\text { GTTCGCCTTTCA } \\
\text { GACCTAC } \\
\text { ACCACTTCATCG } \\
\text { GGATTTA }\end{array}$ & 60 & 138 & $y=-3.288 x+23.1$ & 0.985 & AJ309540 \\
\hline $\begin{array}{l}\text { CXCLil (K60) } \\
\text { (Gallus gallus/ } \\
\text { chicken) }\end{array}$ & $\begin{array}{l}\text { CAAGCACGTTCA } \\
\text { GCGATT } \\
\text { ATTCTTGCAGTG } \\
\text { AGGTCCG }\end{array}$ & 57 & 117 & $y=-3.246 x+24.79$ & 0.994 & AF277660 \\
\hline $\begin{array}{l}\text { CXCLi2 (CAF/IL-8) } \\
\text { (Gallus gallus/ } \\
\text { chicken) }\end{array}$ & $\begin{array}{l}\text { TTGGAAGCCACT } \\
\text { TCAGTCAGAC } \\
\text { GGAGCAGGAGG } \\
\text { AATTACCAGTT }\end{array}$ & 60 & 120 & $y=-3.234 x+22.5$ & 0.993 & AJ009800 \\
\hline $\begin{array}{l}\text { TGF- } \beta 4 \text { (Gallus } \\
\text { gallus/chicken) }\end{array}$ & $\begin{array}{c}\text { AGGATCTGCAGT } \\
\text { GGAAGTGGAT } \\
\text { CCCCGGGTTGT } \\
\text { GTTGGT }\end{array}$ & 61 & 137 & $y=-3.145 x+23.54$ & 0.990 & $M 3 I I 60$ \\
\hline $\begin{array}{l}\text { ¡NOS (Gallus gallus/ } \\
\text { chicken) }\end{array}$ & $\begin{array}{l}\text { CAGCTGATTGG } \\
\text { GTGTGGAT } \\
\text { TTTCTTTGGCCT } \\
\text { ACGGGTC }\end{array}$ & 58 & 158 & $y=-3.245 x+25.8$ & 0.944 & U46504 \\
\hline $\begin{array}{l}\text { I6S (C. jejuni) rRNA } \\
\text { (C. jejuni) }\end{array}$ & $\begin{array}{c}\text { AACCTTACCTGG } \\
\text { GCTTGATA } \\
\text { CTTAACCCAACA } \\
\text { TCTCACGA }\end{array}$ & 52 & 122 & $y=-3.149 x+15.7$ & 0.998 & NC_002163 \\
\hline ciaB (C. jejuni) & $\begin{array}{l}\text { ATATTTGCTAGC } \\
\text { AGCGAAGAG } \\
\text { GATGTCCCACTT } \\
\text { GTAAAGGTG }\end{array}$ & 51 & 157 & $y=-3.357 x+23.7$ & 0.996 & NC_002163 \\
\hline dnaJ (C. jejuni) & $\begin{array}{l}\text { AGTGTCGAGCTT } \\
\text { AATATCCC } \\
\text { GGCGATGATCTT } \\
\text { AACATACA }\end{array}$ & 51 & 117 & $y=-3.166 x+26.3$ & 0.996 & NC_002I63 \\
\hline $\operatorname{racR}(C$. jejuni) & $\begin{array}{c}\text { CTTAAGCGATAA } \\
\text { AGTTGTGG } \\
\text { CTTTTTGTGCGA } \\
\text { CGAAT }\end{array}$ & 51 & 114 & $y=-3.122 x+23.7$ & 0.996 & NC_002163 \\
\hline
\end{tabular}


A slope of -3.32 indicates the PCR reaction has 100\% efficiency [40]. The slopes of all primer pairs are close to each other, from -3.35 to -3.12 (Table 1), suggesting a close efficiency of the amplification between reference and target genes in qPCR. The close efficiency of amplification between target and reference validates the quantification of genes by either the standard curve or the $2^{-\Delta \Delta \mathrm{Ct}}$ methods in further experiments.

\section{Quantification of cytokines and bacterial virulence- associated genes}

The transcripts of cytokine interleukin $1 \beta$ (IL-1 $\beta$ ), IL-6, CXCLi1, CXCLi2, tumor growth factor $\beta 4$ (TGF- $\beta 4$ ) and the inducible nitric oxide synthese (iNOS) were measured in inoculated and mock-inoculated cells using qPCR relative to $\beta$-actin. The transcripts of bacterial virulence-associated genes ciaB, dnaJ and racR in invaded/adhered, suspended and those bacteria treated with various media were quantitatively determined by qPCR relative to $16 \mathrm{~S}$ rRNA, by use of the $2^{-\Delta \Delta C t}$ method previously described [41]. PCR was performed in duplicate including no-template controls.

\section{Measurement of NO production}

Nitric oxide production was determined by measuring nitrite in cell culture media using the Griess Reagent System (Promega) assay according to the manufacture's instruction. The absorbance was read at $550 \mathrm{~nm}$, using a Multiskan EX microtiter plate reader (Thermo Labsystem, Multiskan EX, Denmark).

\section{Statistical analyses}

The values were expressed as the average \pm standard deviation (SD). The data were analyzed for statistical significance using one-way ANOVA (ANalysis Of VAriance, Microsoft Excel). A $p$-value $\leq 0.05$ was considered to be statistically significant.

\section{Authors' contributions}

YPL participated in the development of study design, performed the experiments, collected and interpreted the data, and wrote the manuscripts. HI and MM contributed to the editing of the manuscript and discussions. DDB participated in the development of study design and discussions, interpreted the data and editing the manuscript. All authors read and approved the final manuscript.

\section{Acknowledgements}

We thank Jonas Hoeberg for his assistance in RNA isolation and real time RT-PCR experiments. This work was supported by the Danish Research Council.

\section{References}

I. Skirrow MB: Diseases due to Campylobacter, Helicobacter and related bacteria. J Comp Pathol 1994, I I I: I I3-149.
2. Altekruse SF, Stern NJ, Fields PI, Swerdlow DL: Campylobacter jejuni--an emerging foodborne pathogen. Emerg Infect Dis 1999, 5:28-35.

3. Ruiz-Palacios GM: The health burden of Campylobacter infection and the impact of antimicrobial resistance: playing chicken. Clin Infect Dis 2007, 44:70 I-703.

4. Wassenaar TM, Blaser MJ: Pathophysiology of Campylobacter jejuni infections of humans. Microbes Infect 1999, I:1023-1033.

5. Nachamkin I, Allos BM, Ho T: Campylobacter species and Guillain-Barre syndrome. Clin Microbiol Rev 1998, I I:555-567.

6. Buzby JC, Allos BM, Roberts T: The economic burden of Campylobacter-associated Guillain-Barre syndrome. J Infect Dis 1997, I76 Suppl 2:S192-SI97.

7. Newell DG, Fearnley C: Sources of Campylobacter colonization in broiler chickens. Appl Environ Microbiol 2003, 69:4343-435I.

8. Everest PH, Goossens H, Butzler JP, Lloyd D, Knutton S, Ketley JM, Williams PH: Differentiated Caco-2 cells as a model for enteric invasion by Campylobacter jejuni and C. coli. J Med Microbiol 1992, 37:319-325.

9. Fernandez H, Trabulsi LR: Invasive and enterotoxic properties in Campylobacter jejuni and Campylobacter coli strains isolated from humans and animals. Biol Res 1995, 28:205-2 10.

10. Al-Salloom FS, AI MA, Ismaeel A, Botta GA, Bakhiet M: Campylobacter-stimulated INT407 cells produce dissociated cytokine profiles. J Infect 2003, 47:217-224.

II. Bakhiet M, Al-Salloom FS, Qareiballa A, Bindayna K, Farid I, Botta GA: Induction of alpha and beta chemokines by intestinal epithelial cells stimulated with Campylobacter jejuni. J Infect 2004, 48:236-244.

12. Hickey TE, Baqar S, Bourgeois AL, Ewing CP, Guerry P: Campylobacter jejuni-stimulated secretion of interleukin-8 by INT407 cells. Infect Immun 1999, 67:88-93.

13. Hu L, Hickey TE: Campylobacter jejuni induces secretion of proinflammatory chemokines from human intestinal epithelial cells. Infect Immun 2005, 73:4437-4440.

14. Jones MA, Totemeyer S, Maskell DJ, Bryant CE, Barrow PA: Induction of proinflammatory responses in the human monocytic cell line THP-I by Campylobacter jejuni. Infect Immun 2003, 71:2626-2633.

15. Smith CK, Kaiser P, Rothwell L, Humphrey T, Barrow PA, Jones MA: Campylobacter jejuni-induced cytokine responses in avian cells. Infect Immun 2005, 73:2094-2100.

16. Enocksson A, Lundberg J, Weitzberg E, Norrby-Teglund A, Svenungsson B: Rectal nitric oxide gas and stool cytokine levels during the course of infectious gastroenteritis. Clin Diagn Lab Immunol 2004, I I:250-254.

17. Borrmann E, Berndt A, Hanel I, Kohler H: Campylobacter-induced interleukin-8 responses in human intestinal epithelial cells and primary intestinal chick cells. Vet Microbiol 2007, 124:1 15-124.

18. Sang FC, Shane SM, Yogasundram K, Hagstad HV, Kearney MT: Enhancement of Campylobacter jejuni virulence by serial passage in chicks. Avian Dis 1989, 33:425-430.

19. Kaiser P, Poh TY, Rothwell L, Avery S, Balu S, Pathania US, Hughes S, Goodchild M, Morrell S, Watson M, Bumstead N, Kaufman J, Young JR: A genomic analysis of chicken cytokines and chemokines. J Interferon Cytokine Res 2005, 25:467-484.

20. Griess P: Bemerkungen zu der abhandlung der H.H. Weselsky und Benedikt, Ueber einige azoverbindungen. Chem Ber 1879, 12:426-428.

21. Knudsen KN, Bang DD, Andresen LO, Madsen M: Campylobacter jejuni strains of human and chicken origin are invasive in chickens after oral challenge. Avian Dis 2006, 50:10-14.

22. Hu L, Bray MD, Osorio M, Kopecko DJ: Campylobacter jejuni induces maturation and cytokine production in human dendritic cells. Infect Immun 2006, 74:2697-2705.

23. Wassenaar TM, Engelskirchen M, Park S, Lastovica A: Differential uptake and killing potential of Campylobacter jejuni by human peripheral monocytes/macrophages. Med Microbiol Immunol 1997, I 86: I39-| 44.

24. Kiehlbauch JA, Albach RA, Baum LL, Chang KP: Phagocytosis of Campylobacter jejuni and its intracellular survival in mononuclear phagocytes. Infect Immun 1985, 48:446-45I.

25. Konkel ME, Hayes SF, Joens LA, Cieplak W Jr.: Characteristics of the internalization and intracellular survival of Campylo- 
bacter jejuni in human epithelial cell cultures. Microb Pathog 1992, 13:357-370.

26. Day WA Jr., Sajecki JL, Pitts TM, Joens LA: Role of catalase in Campylobacter jejuni intracellular survival. Infect Immun 2000, 68:6337-6345

27. Naikare H, Palyada K, Panciera R, Marlow D, Stintzi A: Major role for FeoB in Campylobacter jejuni ferrous iron acquisition, gut colonization, and intracellular survival. Infect Immun 2006, 74:5433-5444.

28. Wuyts A, Proost P, Lenaerts JP, Ben-Baruch A, Van DJ, Wang JM: Differential usage of the CXC chemokine receptors $I$ and 2 by interleukin-8, granulocyte chemotactic protein-2 and epithelial-cell-derived neutrophil attractant-78. Eur J Biochem 1998, 255:67-73.

29. Hickey TE, McVeigh AL, Scott DA, Michielutti RE, Bixby A, Carroll SA, Bourgeois AL, Guerry P: Campylobacter jejuni cytolethal distending toxin mediates release of interleukin-8 from intestinal epithelial cells. Infect Immun 2000, 68:6535-654I.

30. Young KT, Davis LM, Dirita VJ: Campylobacter jejuni: molecular biology and pathogenesis. Nat Rev Microbiol 2007, 5:665-679.

31. Datta S, Niwa H, Itoh K: Prevalence of II pathogenic genes of Campylobacter jejuni by PCR in strains isolated from humans, poultry meat and broiler and bovine faeces. I Med Microbiol 2003, 52:345-348.

32. Fouts DE, Mongodin EF, Mandrell RE, Miller WG, Rasko DA, Ravel J, Brinkac LM, DeBoy RT, Parker CT, Daugherty SC, Dodson RJ, Durkin AS, Madupu R, Sullivan SA, Shetty JU, Ayodeji MA, Shvartsbeyn A, Schatz MC, Badger JH, Fraser CM, Nelson KE: Major structural differences and novel potential virulence mechanisms from the genomes of multiple campylobacter species. PLoS Biol 2005, 3:el5.

33. Konkel ME, Kim BJ, Klena JD, Young CR, Ziprin R: Characterization of the thermal stress response of Campylobacter jejuni. Infect Immun 1998, 66:3666-3672.

34. Ziprin RL, Young CR, Byrd JA, Stanker LH, Hume ME, Gray SA, Kim $B$ J, Konkel ME: Role of Campylobacter jejuni potential virulence genes in cecal colonization. Avian Dis 200 I, 45:549-557.

35. Bras AM, Ketley JM: Transcellular translocation of Campylobacter jejuni across human polarised epithelial monolayers. FEMS Microbiol Lett 1999, I79:209-2I5.

36. Konkel ME, Kim BJ, Rivera-Amill V, Garvis SG: Bacterial secreted proteins are required for the internaliztion of Campylobacter jejuni into cultured mammalian cells. Mol Microbiol 1999, 32:691-70I.

37. Rivera-Amill V, Konkel ME: Secretion of Campylobacter jejuni Cia proteins is contact dependent. Adv Exp Med Biol 1999 473:225-229.

38. Rivera-Amill V, Kim BJ, Seshu J, Konkel ME: Secretion of the virulence-associated Campylobacter invasion antigens from Campylobacter jejuni requires a stimulatory signal. J Infect $D$ is 200I, 183:I607-16I6.

39. Bang DD, Nielsen EM, Knudsen K, Madsen M: A one-year study of campylobacter carriage by individual Danish broiler chickens as the basis for selection of Campylobacter spp. strains for a chicken infection model. Epidemiol Infect 2003, 130:323-333.

40. Ginzinger DG: Gene quantification using real-time quantitative PCR: an emerging technology hits the mainstream. Exp Hematol 2002, 30:503-512.

4I. Livak KJ, Schmittgen TD: Analysis of relative gene expression data using real-time quantitative PCR and the 2(-Delta Delta C(T)) Method. Methods 200I, 25:402-408.
Publish with Biomed Central and every scientist can read your work free of charge

"BioMed Central will be the most significant development for disseminating the results of biomedical research in our lifetime. "

Sir Paul Nurse, Cancer Research UK

Your research papers will be:

- available free of charge to the entire biomedical community

- peer reviewed and published immediately upon acceptance

- cited in PubMed and archived on PubMed Central

- yours - you keep the copyright
BioMedcentral 